\title{
Corporate Sectoral Investments and Economic Growth in Nigeria: Evidence from the Capital Market
}

\author{
Prince C. Nwakanma, Ph.D \& Ikechukwu S. Nnamdi, Ph.D \\ Senior Lecturers, Department of Finance and Banking \\ University of Port Harcourt, Port Harcourt, Nigeria \\ E-mail: nwakanma5@yahoo.com; snnamdi95@yahoo.com
}

Received: November 4, 2012

Accepted: December 5, $2012 \quad$ Online Published: December 6, 2012

doi:10.5430/jbar.v1n2p99

URL: http://dx.doi.org/10.5430/jbar.v1n2p99

\begin{abstract}
This study aims at articulating an empirical basis for prioritizing corporate sectoral investments in the Nigerian capital market and also, evaluating the extent to which market capitalization of the Nigeria stock exchange reflects the net sectoral investments of corporate organizations quoted therein. Covering the period 1984 to 2009 (26yrs), the study population consists of all the thirty (30) classified sectors of the market, while the study sample is made up of the eighteen (18) sectors with operational activities over the period of study. Multiple correlation and stepwise regression techniques are utilised and the relevant hypotheses tested at 0.05 level of significance. The F-test and F-change test statistics are employed. The results establish a significant multiple correlation between the Nigerian Stock Market Capitalization and Corporate net sectoral investments, while net corporate investments in four sectors of capital market activity - petroleum marketing, building materials, packaging and banking are found to significantly contribute to variations in Nigeria's GDP. It is recommended that these four sectors should continually enhance their capitalizations to facilitate further investments and also, engage in product diversification. Further, the banking sector is recommended to adopt sectoral contributions to the GDP as one of the plausible criteria for lending decisions, while the resolution of an optimal portfolio for sectoral investments in the Nigerian Capital Market is recommended as an issue arising from this study for further research.
\end{abstract}

Keywords: Net corporate investments / assets, Net sectoral investments, Market resource allocation, Market capitalization and Economic growth

\section{Overview}

Human productive activities involve the employment of resources which include various forms of fixed and movable assets, men and money. These resources are employed to generate profitable results that ultimately enhance shareholders' wealth. Investment projects, particularly those executed by large corporate organizations, facilitate national economic growth by increasing the output of goods and services. Given this scenario, corporate organizations contribute to the growth and stability of national economies by skillfully identifying and appraising potentially viable investment opportunities that exist in various sectors of their target economies. Consequently, they mobilize financial resources, other factor inputs and also, engage in the management of the productive and distributive processes in order to earn optimal returns. Okafor (1983) argues that investment activities are deemed essential for the improvement of the quality of human life and economic prosperity of nations because they give rise to output of goods and services. Resultantly, the extent to which these productive investment activities are executed and managed in any economy has largely been used as an index for measuring the country's level of economic growth and productive efficiency. In this connection, economic development of nations, particularly in the less developed economies, has virtually been evaluated on the basis of the level of prevailing investment activities as well as the rates of improvement in the efficiencies of available factor inputs.

Todaro and Smith (2009) express the concern of traditional economics as the employment of resources over time. They argue that this concern is to ensure a continuous and large scale availability of significant number of goods and services over time. However, these human productive processes are often organized through highly capitalized organizations with diversified ownership structure. Their investment, financing decisions and strategies are equally complex. As the economy grows, increasing funds are required to support investment activities in the various sectors of the economy. However, for cost effectiveness, these required funds need to be effectively mobilized and allocated 
to the efficient productive units in the economy as they have the capacity to optimally utilize the resources and effectively return the funds to the funding sources. Since the investment profiles of most real sector projects are mainly long-term, they correspondingly require long-term funds, mostly available in the capital market. The capital market is sophisticated and has capacity to guarantee greater efficiency in resources allocation. Consequently, an efficient capital market can theoretically provide basis for predictable changes in sectoral contributions to a nation's economic growth.

Over the years, many corporate concerns have gone public in Nigeria. It represents a conscious effort to access greater quantum and diversified funds for investment in various sectors of the Nigerian economy. The capital market has continued to grow as evidenced by the entry of substantial new investors. Also, various business combinations involving corporate mergers and acquisitions have occurred. Further, the second tier market has also developed to accommodate quotation of less capitalized firms on less stringent terms and conditions. It is evident that some firms have listed additional securities in order to achieve diversified funding necessary to achieve lower cost of funds. As business opportunities continue to expand in modern day free enterprise economy, identification and implementation of varied investment programmes will continue to grow and deepen in various sectors of the Nigerian economy. Consequently, the optimal distribution of corporate investment projects among various sectors of the capital market will not only be important, but will remain fundamental in sustaining the direction and level of growth of the Nigerian economy.

\section{Statement of Problem}

Quoted corporate entities in Nigeria have over the years, invested in several sectors of the Nigerian economy. Osaze (2007) observed that an efficient capital market facilitates optimal allocation of scarce productive resources at both individual and general market levels. The Nigerian government has initiated polices and incentives designed to encourage local investments and also, attract more foreign direct investments. Nigeria's Industrial Policy (2006) and Investments and Securities Act No. 45 (1999) are replete with such investment incentives including tax and export processing concessions. In that connection, government has concentrated her policy efforts on capacity building, technological development, employment generation and other variables designed to strengthen the macro-economy. Central Bank of Nigeria (2007) argued that an active capital market facilitates resource mobilization. The market ensures efficient allocation through changes in wealth ownership and composition, thus enhancing capital formation and economic growth. A significant number of studies on capital markets therefore, tend to revolve around the identification of the potential capacities of the markets to meet these core expectations.

Ojo (1998) argued that acquisition of industrial capabilities in any country requires the blending of diverse resources including finance, which the capital market functions to provide. Osawonyi (2006) on the other hand, identified various sources of imperfection in the Nigerian capital market that tend to constrain supply of capital funds. Also, Muoghalu and Ezirim (2002), examined the extent to which financial market operations impact on Nigeria's economic growth. In the same vein, Okpara (2006), Isu and Ndubuisi (2002), Iyoha and Ogun (2005), Akujuobi (2007), Akujuobi and Nwaezeaku (2007), Akujuobi and Akujuobi (2007), Ogbulu (2009) and Okpara (2010) all found significant relationships between capital market activity and Nigeria's economic growth.

Interestingly, most previous studies proxied the Nigerian capital market with either market capitalization, traded volumes or traded values of securities. However, trading is largely a secondary market activity and basically, does not add value to corporate productive potentials. On the contrary, corporate net assets/investments from finance and accounting perspectives constitute the basic productive resources available and employed by any given corporate entity for the production of goods and services within a given accounting period. An efficient capital market for all intents and purposes, should theoretically capture the productive potentials of the firms quoted therein. Gunderson (1976) and Kemp (1978) surveyed the influences of the various sectors of economic activity on Europe and America's rapid economic growth and concluded that the order of sectoral activity contributions to national economic growth could radically differ among nations. Explicitly, what is the objective nature of sectoral prioritization of corporate sectoral investments in Nigeria? Of significant concern also, is the extent to which market capitalization as an accepted proxy for the capital market so far, correlates with the net sectoral investments of the firms quoted on the Nigerian Stock Exchange. The above key issues therefore, constitute the core problem of this study.

\section{Objectives and Significance of Study}

Broadly aimed at ascertaining the extent to which corporate sectoral investments in the capital market contribute to Nigeria's economic growth, specifically, the study hopes to; 
(i) Evaluate the extent to which the market capitalization of the Nigerian Stock Exchange reflects the net sectoral assets/investments of firms quoted therein.

(ii) Establish an objective order for prioritization of the classified sectors of the Nigerian capital market based on the contributions of their net sectoral investments to Nigeria's economic growth.

In terms of significance, the results are hoped to reveal the relative contributions of the existing quoted companies classified in the various sectors of the Nigerian capital market and by implication, to Nigeria's economic growth and returns to the corporate investors. This information may be valuable in circumstances where the companies might wish to deepen or diversify their investments in Nigeria. At policy level, the results are expected to assist the Nigerian government in identifying the sectors of the capital market which policy actions targeted on them may boost or retard economic growth. The investors constitute a core group in any capital market. Consequently, the results are hoped to assist both local and international capital market investors in identifying the quoted firms engaged in viable sectors of the economy. The anticipation is that these firms are more likely to remain profitable over a longer period of time, thereby providing objective basis for assurance of sustained rewards to the investors.

The stockbrokers and investment service advisers are hoped to benefit from this study in terms of provision of objective information that may improve the quality of advisory services which they could render to their clients.

\section{Scope and Limitations of Study}

This study covers the period 1984 to 2009 and is constrained by the following;

i. Variations in the financial reporting periods of firms classified into any given sector of economic activity by the Nigerian Stock Exchange exist. However, no attempt was made in this study to adjust for these variations in reporting periods in order to achieve a uniform accounting date as it was assumed that these differences in accounting dates would be normalized.

ii. The recent wave of business combinations (merges and acquisitions) in Nigeria affected a lot of firms and pruned down the number of companies quoted on the stock exchange. To this extent, the financials of the companies were recorded to capture both their pre-merger and post-merger/combination identifies. This has invariably, affected the study in terms of the number of companies existing at any given point in time, although it did not affect the estimated values of corporate sectoral investments.

\section{Study Hypotheses}

The hypotheses for this study in their null (Ho) forms are:

$\mathrm{Ho}_{1}$ : There is no significant correlation between the entire set of net sectoral investments in the Nigerian capital market and the market capitalization of the Nigerian Stock Exchange.

$\mathrm{Ho}_{2}$ : The contribution of net investments in each classified sector of capital market activity is not significantly valuable in explaining variations in Nigeria's gross domestic product.

\section{Review of Related Studies}

Existing studies on the Nigerian capital market could broadly be classified as either empirical on non-empirical. However, most of the empirical literature have proxied the Nigerian capital market with either market capitalization or traded value/volume of securities. Gap identification in existing literature provides therefore, a point of departure for this study which basically approaches the subject of corporate contributions to Nigeria's economic growth from the perspective of net corporate sectoral investments. Akujuobi and Akujuobi (2007) estimated the contributions of the preferred sectors of the Nigerian capital market to economic growth over the period of 1986 to 2004 and proxied the preferred sectors of the market by volume of traded securities. Onwumere and Modebe (2007) expressed preference for dominance and quotation of machine tools industries as panacea for Nigeria's economic growth and sustenance. Unfortunately, they failed to provide any empirical evidence on the influence of machine tools sector on the economic growth of nations. Irrespective of the fact that the machine tools sector has not been quoted in Nigeria, their argument fundamentally negates the fact that comparative advantages and resource endowment obviously differ among nations. Thus, the place of machine tools sector in the economic growth of nations could be radically altered on specific country basis. To this extent, the conclusions of the study could be spurious as there may not empirically, prevail any universal order for the place of the machine tools sector.

Adenuga and Akpan (2007) applauded the role of financial institutions in the economic growth of nations and recommended the establishment of varied types of financial institutions in Nigeria for accelerated economic growth. However, as appealing as their recommendation is, they failed to show any empirical evidence as to the types of 
financial institutions that were likely to be of greater influence on the Nigerian economy. In the same direction, while Akujuobi and Nwaezeaku (2007) identified the "seemingly increasing returns on Nigerian banking sector stocks in the face of declining capital market performance up to 2003, the study did not appreciate the fact that most of the reported bank profits over their period of study were not operationally supported. A significant number of Nigerian banks within that period were involved in foreign exchange malpractices which inflated their earnings. In other instances, some other banks were involved in window dressing to suppress deteriorating credits contrary to the provisions of prudential guidelines which inflated their reported profits. The trend eventually led to the 2004/2005 bank reforms which induced a significant level of recapitalization and consolidation measures within the Nigerian banking sector.

Okpara (2006) viewed the Nigerian capital market as a facilitator of the economy. However, relating volume of traded shares (a secondary market activity) to Nigeria's GDP is financially and economically deficient. A mere swop of securities in the secondary market does not add to productive capacities of quoted firms. Primary market transactions would have been employed. On the other hand, Nwakanma et al (2010), provided a valuable framework for appraising sectoral entrepreneurial activities in Nigeria and their influences on the GDP. However, the study failed to recognize the inelastic nature of demand for Nigeria's crude petroleum (a primary product). Iyoha and Ogun (2005) estimated the predictive potentials of the Nigerian stock market in relation to future economic activities. They employed the Granger causality model and found that past stock market capitalizations could significantly be relied on to predict future trends in Nigeria's economic performance. Gunderson (1976) provided a path-breaking appraisal of sectoral contributions to economic activity in the United States of America and their presumed influences on America's rapid economic growth. Although largely descriptive, it provides an insight and spring board for an empirical enquiry into the sectoral roles of investments in the growth of any nation. In the same vein, Kemp (1978) offered a valuable survey of industrialization patterns in Europe involving economic sectors of activity. Despite the descriptive nature of the study, it provides generally, a scholarly motivating ground for specific country studies. This emanates, from the study's objective conclusion that the order of sectoral activity contributions to national economic growth could differ among nations. On the whole, it could be observed that available empirical studies so far, have largely employed total market capitalization, volume and/or value of traded securities as proxies for the Nigerian capital market. Attempts have so far, not been observed towards decomposing the market capitalization into the constituent sectoral capitalizations and subsequently, relating them to the GDP, worth more, net sectoral investments. In view of this study's problem statement, these observed defects represent a major gap which invariably, underscores the approach adopted in this study.

\section{Methodology}

This study adopted the classifications provided by the Nigerian Stock Exchange. Resultantly, all the firms quoted in both the first and second tiers of the market were classified into their operational sectors as shown in appendix I.

\subsection{Study Population, Sample Size, Sources of Data and Data Collection Instrument}

The population for this study is defined as all the thirty (30) classified sectors of economic activity in the Nigerian capital market as outlined in the Nigerian Stock Exchange FACTS Book corresponding to appendix I. The sample size consists of the eighteen (18) classified sectors of the Nigerian Stock Exchange that existed over the period of study as shown in appendix II. However, some other sectors were introduced after 1984 and as such, do not meet the time dimension of the scope of this study. Further, the annual reports of Central Bank of Nigeria, the Nigeria Stock Exchange FACTS Book and the published statements of the quoted companies constitute the secondary sources of data for this study. On the whole, the required information was collated through employment of the data collection/research instrument shown as appendix III.

\subsection{Model Specifications}

Following Nwakanma et al (2010), arguments developed by Gunderson (1976) and $\operatorname{Kemp}(1978)$ as they relate to the problem of this study, we specify the following functional models.

$$
\text { (i) } \mathrm{MCP}_{\mathrm{t}}=\mathrm{F}\left(\mathrm{X}_{1 \mathrm{t}}, \mathrm{X}_{2 \mathrm{t}}, \mathrm{X}_{3 \mathrm{t}}-\cdots-\mathrm{X}_{\mathrm{nt}}\right)
$$

Where:

$\mathrm{MCP}_{\mathrm{t}}=$ total market capitalization at time $\mathrm{t}$.

$\mathrm{X}_{1 \mathrm{t}}-\mathrm{X}_{\mathrm{nt}}=$ net corporate investments in each of the classified sectors of the Nigerian capital market. 
The resulting null hypothesis on the estimated multiple correlation between total market capitalization and the entire set of net sectoral corporate investments will be rejected if and only if the computed $\mathrm{F}$ - value is greater than the critical $\mathrm{F}-$ value at the corresponding degree of freedom and the preferred 0.05 level of significance.

$$
\text { (ii) } \mathrm{GDP}_{\mathrm{t}}=\mathrm{F}\left(\mathrm{X}_{1 \mathrm{t}}, \mathrm{X}_{2 \mathrm{t}}, \mathrm{X}_{3 \mathrm{t}} \ldots \ldots \mathrm{X}_{\mathrm{nt}}\right)
$$

Where:

$\mathrm{GDP}=$ gross domestic product in year $\mathrm{t}$.

$\mathrm{X}_{1 \mathrm{t}}-\mathrm{X}_{\mathrm{nt}}=$ net corporate investments in each of the classified sectors of the capital market.

Conventionally, all the assumptions of linearity, homoscendasticity, randomness, uncorrelated succession, zero mean for expected values, constant variance, normality in distribution and zero covariance between disturbance terms are made with respect to all the variables. In all, the Statistical Package for the Social Sciences (SPSS) software version 17.0 was employed with minimum of 0.05 level of significance assumed.

Stepwise regression analysis was employed to determine the relative importance of the various net sectoral investments in accounting for the variations in Nigeria's gross domestic product.

Maddala (2007) asserts that $\mathrm{R}$ - Square changes in the stepwise regression analysis denote the contributions of each of the explanatory variables introduced into the equation at each step. The decision rule is to reject the null hypothesis in respect of the contribution of any net sectoral investment which F-change value is equal to or exceeds the critical F-distribution value at the corresponding $\mathrm{Q}$ and $\mathrm{N}-\mathrm{P}-\mathrm{I}$ degree of freedom and 0.05 level of significance. Here, $\mathrm{Q}$ is the number of variables entered at the particular stage, $\mathrm{N}$ is the number of cases and $\mathrm{P}$ is the total number of explanatory variables (net corporate sectoral investments) in the equation.

\subsection{Apriori Expectations}

This study expects;

(i) a statistically significant multiple correlation coefficient between total stock market capitalization of the Nigerian Stock Exchange and the entire set of net corporate sectoral investments in the classified sectors of the capital market.

(ii) a statistically significant contribution of net corporate investments in each sector of classified capital market activity to variations in Nigeria's gross domestic product.

\section{Data Presentation and Analysis:}

The data collected for this study are presented in appendix IV and contain information on Nigeria's gross domestic product (GDP), total stock market capitalization and net corporate sectoral investments for the sampled sectors over the period of $1984-2009$.

\subsection{Data Analysis}

It is pertinent to assert that conglomerates sector, $X_{9}$ was excluded from the analysis by the system owing to its failure to meet the specified PIN 0.05 entry criterion thus, reducing the processed sample size in the analysis to seventeen (17). Finally, the possibility of a significant level of multicollinearity among the net corporate sectoral investments was verified. The tolerance values of the explanatory variables entered in the equations provide adequate checks for the existence of multicollinearity within the SPSS framework. The results were verified and the existing levels of interdependency among the net sectoral investments employed were all within tolerable limits, thus making for meaningful analysis.

8.1.1 Results of Multiple Correlation Between Nigerian Stock Market Capitalization And The Entire Set of Net Sectoral Investments

Table 1 below shows the above captioned results;

\section{Insert Table 1 here}

From table 1, the level of association between total stock market capitalization and the entire set of net sectoral investments in the Nigerian capital market (multiple R) is 1.00 and is significant at 0.000 level.

8.1.2 Stepwise Regression Analysis of Nigeria's Gross Domestic Product on the Entire Set of Net Sectoral Investments in the Capital Market

The results of the above analysis are summarised in table 2 below:

\section{Insert Table 2 here}


Table 2 shows that Petroleum Marketing $\left(\mathrm{X}_{25}\right)$, building materials $\left(\mathrm{X}_{6}\right)$, Packaging $\left(\mathrm{X}_{24}\right)$ and banking $\left(\mathrm{X}_{4}\right)$ sectors were selected in steps 1, 2, 3 and 4 respectively. R-square values denote the cumulative percentage change in the variance of Nigeria's GDP which is explained by net sectoral investments entered progressively in the stepwise regression sub-programme. Consequently, the R-square value of 0.912 for petroleum marketing sector in the first step implies that net investments in petroleum marketing sector explain $91.2 \%$ of variations in Nigeria GDP, while the combined entry of petroleum marketing and building materials explain $93.8 \%$ of variations in the GDP. Subsequently, combined entries of petroleum marketing, building materials and packaging sectors explain $95.8 \%$ of variations in GDP while the additional entry of banking sector provides for a combined explanation of $97.2 \%$ of variances in Nigeria's GDP.

The R-square - change values on the other hand, represent additional contribution attributed to each of the net sectoral investments that entered the stepwise regression analysis in explaining the observed variances in Nigeria's GDP. With respect to table 2, the results imply that of the four net sectoral investments that entered the stepwise process, the net investments in the petroleum, building materials, packaging and banking sectors contributed $91.2 \%$, $2.5 \%, 2.1 \%$ and $1.3 \%$ respectively to changes in Nigeria's GDP.

\section{Tests of Hypotheses}

To ascertain the extent to which our tentative statements are in agreement with the results of this study, the hypotheses are hereunder, tested with the relevant test statistics. The F-statistics was employed. The degree of freedom relating to the F-statistic is expressed as;

$$
\text { Fq; N-p-1. }
$$

Where; $\quad \mathrm{Q}=$ number of variables entered (i.e. stock market capitalization and 17 net sectoral investments $=18$ ).

$\mathrm{N}=$ number of cases.

$\mathrm{P}=$ total number of sectors in the equation.

On substitution, the degree of freedom corresponds to $F_{18 ; 424}$

The critical table F-value at 0.05 level of significance and degree of freedom $F(18,424)$, is 1.66 . However, the calculated F-value is 2412.714 for the multiple R of 1.00. Since the calculated F-value is greater than the critical value, the null hypothesis is rejected. Therefore, there is a significant correlation between total market capitalization of the Nigerian Stock Exchange and the entire set of net corporate sectoral investments.

\subsection{Test of Hypothesis II}

To test the statistical significance of the contributions of net investments in each sector of capital market activity to the GDP, the F-change statistic was adopted. Consequently, we restate the following null and alternate hypotheses;

$\mathrm{Ho}_{1}$ : The contribution of net investments in each classified sector of capital market activity is not valuable in explaining variations in Nigeria's gross domestic product.

$\mathrm{Ho}_{2}$ : The contribution of net investments in each classified sector of capital market activity is valuable in explaining variations in Nigeria's gross domestic product.

From table 2, the F-change statistic values for petroleum marketing (250.111), building materials (9.260), packaging (11.010) and banking (9.950) are all statistically significant at 0.05 level. The null hypothesis is consequently rejected in respect of all the above four sectors, while the alternate hypothesis is accepted for the rest of the sectors in the study.

\section{Discussion of Findings}

The results of the multiple correlation and stepwise regression analyses provide the background for the discussion of the findings of this study. The perfect multiple correlation coefficient $(\mathrm{R}=1)$, between Nigerian Stock Market capitalization and the entire net sectortal investments of quoted companies suggests that the market perfectly reflects the sectoral productive potentials of quoted firms proxied by their net sectoral investments/assets. To this extent, net corporate sectoral assets could also, serve as a reliable proxy for the Nigerian capital market as market capitalization does. The $\mathrm{R}^{2}$ - change values in the stepwise regression analysis approximate the contributions of the net sectoral investments to variations in Nigeria's GDP. Correspondingly, petroleum marketing, building materials, packaging and banking sectors significantly contributed $91.2 \%, 2.5 \%, 2.1 \%$ and $1.3 \%$ respectively to variations in Nigeria's GDP. The results support the evidence that the petroleum sector dominates the Nigerian economy and suggest the obvious need for product diversification in the petroleum sector. 
Multiplier affects result from investments in the production and utilization of building materials products. Thus, expenditures on building materials have potential capacities to lubricate the economy by inducing associated spending. In this connection, expenditures on construction material relating to all public and private construction projects have influenced the GDP significantly.

Packaging products are widely used for domestic and industrial purposes and consequently attract multiple demands for diversified purposes thereby, influencing the economy. Finally, the banking sector's significant contribution to variances in Nigeria's GDP evidences the important influence of the sector in the economic growth process. It might have resulted from the financial support which the banking sector provides for other sectors. Also, it implicates the potential capacity of the banking sector to propel the rest other sectors that presently appear less viable into contributing significantly to Nigeria's GDP in the nearest future.

\section{Conclusions}

From the results of this study, it is concluded that the Nigerian Stock Market significantly reflects the sectoral net investments of companies quoted therein. Further, among the various sectors of the Nigerian capital market, corporate net investments in the petroleum marketing, building materials, packaging and banking sectors respectively, are the most valuable in predicting Nigeria's gross domestic product hence, economic growth.

\section{Recommendations}

The vital influence of the capital market in the economic growth process necessitates the adoption of some measures to enhance its operations. This invariably informs the following recommendations.

(i) The petroleum marketing, building materials, packaging and banking sectors should be encouraged through self-induced and market motivated initiatives to attract more investible funds for expansion of their investment activities. Also, product diversification in all the sectors is critical to enhance their performance.

(ii) The banking sector specifically, needs to expand its present branch network. However, it is recommended that such expansion should be done in a cost effective manner.

(iii) The determination of priority sectors for government policy incentives should reflect both market and national economic interests. In this direction, it is recommended that public objective decisions on such issues should be based on the contributions of investments in those sectors to Nigeria's economic growth.

(iv) The banks are recommended to employ sectoral productivity as one of the plausible criteria for bank lending decisions among others. The quantum and level of significance of a sector's contribution to Nigeria's GDP for all reasonable intents and purposes could serve as a proxy for the profitability/viability of corporate operations in that sector thereby, serving as an indicator for potential return of loaned funds.

(v) From portfolio point of view, this study has not addressed the problem of achieving an optimally diversified portfolio of net sectoral investments in the Nigerian capital market given the risk-return characteristics of the activity sectors there in. This is necessary in order to maximize shareholder's wealth and Nigeria's GDP. Consequently, an articulation of a workable algorithm for this task and the resolution of this optimal portfolio for corporate net sectoral investments in the Nigerian capital market need to be addressed subsequently.

\section{References}

Adenuga, A. O. and Akpan, N. I. (2007). Financial Resource Mobilization And Investment In Nigeria: The Role of The Financial Sector, Bullion, Vol. 31, No.1. Central Bank of Nigeria (Jan/March).

Akujuobi, A.B.C. (2007). Assessing The Impact Of Capital Market On Industrial Development: The Case Of Nigeria, International Journal Of Development And Management Review, Vol.2, No.1.

Akujuobi, A.B.C and Akujuobi, L.E. (2007). The Capital Market And Economic Development - A Prediction Model, Nigerian Journal Of Economic And Financial Research, Vol.1,No.3. (July).

Akujuobi, A.B.C. and Nwaezeaku, N.C. (2007). Predicting The Influence of The Preferred Sectors On The Nigerian Capital Market, International Journal Of Development And Management Review, Vol. 1, No1., (April).

Central Bank of Nigeria. (2007). Capital Market Dynamics In Nigeria: Structure, Transaction Cost And Efficiency, (1980 -2006)", Abuja, Research and Statistics Dept, CBN.

Federal Government Of Nigeria. (1999). Investments And Securities Act No. 45, 1999, Lagos, Federal Government Press.

Federal Government Of Nigeria. (2006). Industrial Policy Of Nigeria: Targets, Polices, Incentives, Guidelines And Institutional Framework, Abuja, Federal Ministry Of Industries. 
Gunderson, G. (1976). A New Economic History Of America, New York, McGraw-Hill Book Coy.

Iyoha, F. O. and Ogun, T. P. (2005). The Nigerian Stock Market And Future Economic Activities, Union Digest, Vol. 9 , Nos 1 \& 2 (June)

Isu, H.O. and Ndubuisi, P. (2002). Capital Market And Industrial Development In Nigeria: An Empirical Investigation (1981 -1992), Journal of Finance, Banking And Investment, Vol. 2, No.2.

Kemp, T. (1978). Historical Patterns of Industrialization, New York, Longman.

Maddala, G. S. (2007). Introduction to Econometrics, New Delhi, Wiley-India.

Muoghalu, M. and Ezirim, C.B. (2002). Analysis Of Financial Markets Operations And Macro-economic Performance Of A Developing Economy: The African Experience, Papers And Proceedings, $28^{\text {th }}$ Annual Meeting, Academy Of Economics And Finance. (Feb 14-17), Mississippi.

Nnamdi, I. S. (2011). Corporate Sectoral Investments and Economic Growth in Nigeria: Evidence From The Capital Market, Unpublished Ph.D Dissertation, Abia State University, Uturu, Nigeria.

Nwakanma, P.C., Nwakanma, H. and Thompkins, G. (2010). Entrepreneurial Productivity: Sectoral Contribution To The GDP of A Developing Economy, International Business and Economics Research Journal, Vol. 9. No. 7.

Ogbulu, O. M. (2009). Capital Market Development And Economic Growth In Nigeria: Application of Co-Integration And Causality Tests, Journal of Finance, Banking and Investment, Vol. 3. No. 1. (April).

Ojo, M. O. (1998). Developing Nigerian Industrial Capabilities through Public Quotations As A Key For Sustainable Economic Growth Bullion, Vol. 22, No. 3, (July/Sept.).

Okafor, F. O. (1983). Investment Decisions, Evaluation Of Projects And Securities, London, Cassell.

Okpara, G. C. (2006). Capital Market And The Development Of The Nigerian Economy, Nigerian Journal Of Economic And Financial Research, Vol. 1, No. 1, (March).

Okpara, G. C. (2010). Do Emerging Financial Markets Impact on Emerging Opportunity Set? A Dynamic Analysis of Nigerian Case, Journal of Sustainable Development In Africa, Vol. 12. No. 3.

Onwumere, J. U. J. and Modebe, N. J. (2007). The Capital Market And Nigeria's Quest for Economic Self-Reliance, Journal Of Economic And Financial Research, Vol 1. No.3.

Osawonyi, I.O. (2006). Capital Market Imperfections And Community Economic Development In Nigeria, Nigerian Academy Of Management Journal, Vol.1.No.1.(Oct).

Osaze, E.B. (2007). Capital Markets: African And Global, Lagos, Book House Coy.

Todaro, M. P. and Smith, S. C. (2009). Economic Development, New York, Addison - Wesley.

Table 1. Results of Multiple Correlation Analysis Between The Entire Set of Net Sectoral Investments And Total Market Capitalisation of The Nigerian Stock Exchange

\begin{tabular}{|l|l|l|l|l|}
\hline R & R-Square & Adjusted R-Square & F & Sig.f \\
\hline 1.00 & 1.00 & 0.999 & 2412.714 & 0.000 \\
\hline
\end{tabular}

Source: Output from SPSS process.

Table 2. Summary Results Of Stepwise Regression Analysis of Nigeria's Gross Domestic Product on Net Sectoral Investments

\begin{tabular}{|l|l|l|l|l|l|l|l|l|l|l|l|}
\hline Step & $\begin{array}{l}\text { Variables } \\
\text { Entered }\end{array}$ & $\begin{array}{l}\text { Name of Sector } \\
\text { Entered }\end{array}$ & $\begin{array}{l}\text { Details of } \\
\text { variables entered }\end{array}$ & $\mathbf{R}$ & R-square & $\begin{array}{l}\text { R-square } \\
\text { change }\end{array}$ & F-value & Sig. F & $\begin{array}{l}\text { F-change } \\
\text { value }\end{array}$ & $\begin{array}{l}\text { Sig f-change } \\
\text { Partial } \\
\text { correlation } \\
\text { coefficient }\end{array}$ \\
\hline 1 & $\mathrm{X} 25$ & $\begin{array}{l}\text { Petroleum } \\
\text { marketing }\end{array}$ & $\mathrm{X} 25$ & 0.955 & 0.912 & 0.912 & 250.111 & $0.000^{* *}$ & 250.111 & $0.000^{* *}$ & 0.955 \\
\hline 2 & $\mathrm{X} 6$ & $\begin{array}{l}\text { Building } \\
\text { Materials }\end{array}$ & $\mathrm{X} 25, \mathrm{X} 6$ & 0.968 & 0.938 & 0.025 & 172.723 & $0.000^{* *}$ & 9.260 & $0.006^{* *}$ & 0.536 \\
\hline 3 & $\mathrm{X} 24$ & Packaging & $\mathrm{X} 25, \mathrm{X} 6, \mathrm{X} 24$ & 0.979 & 0.958 & 0.021 & 168.935 & $0.000^{* *}$ & 11.010 & $0.003^{* *}$ & -0.576 \\
\hline 4 & $\mathrm{X} 4$ & Banking & $\mathrm{X} 25, \mathrm{X} 6, \mathrm{X} 24, \mathrm{X} 4$ & 0.986 & 0.972 & 0.013 & 180.730 & $0.000^{* *}$ & 9.950 & $0.005^{* *}$ & -0.730 \\
\hline
\end{tabular}

** = Significant at 0.05 level

Source: Output from SPSS process. 
Appendix 1. Sectoral Classification of Companies Quoted in the Nigerian Stock Exchange with Study Codes

\begin{tabular}{|l|l|}
\hline SECTORAL CLASSIFICATIONS & STUDY CODE \\
\hline Agriculture/Agro-Allied & $\mathrm{X} 1$ \\
\hline Airline Services & $\mathrm{X} 2$ \\
\hline Automobile and Tyre & $\mathrm{X} 3$ \\
\hline Banking & $\mathrm{X} 4$ \\
\hline Breweries & $\mathrm{X} 5$ \\
\hline Building materials & $\mathrm{X} 6$ \\
\hline Chemicals and Paints & $\mathrm{X} 7$ \\
\hline Computer and Office equipment & $\mathrm{X} 8$ \\
\hline Conglomerates & $\mathrm{X} 9$ \\
\hline Construction & $\mathrm{X} 10$ \\
\hline Engineering Technology & $\mathrm{X} 11$ \\
\hline Food/Beverages and Tobacco & $\mathrm{X} 12$ \\
\hline Foot wear & $\mathrm{X} 13$ \\
\hline Health care & $\mathrm{X} 14$ \\
\hline Hotel and Tourism & $\mathrm{X} 15$ \\
\hline Industrial/Domestic products & $\mathrm{X} 16$ \\
\hline Insurance & $\mathrm{X} 17$ \\
\hline Leasing & $\mathrm{X} 18$ \\
\hline Machinery marketing & $\mathrm{X} 19$ \\
\hline Managed funds & $\mathrm{X} 20$ \\
\hline Maritime & $\mathrm{X} 21$ \\
\hline Mortgage companies & $\mathrm{X} 22$ \\
\hline Memorandum Quotation & $\mathrm{X} 23$ \\
\hline Packaging & $\mathrm{X} 24$ \\
\hline Petroleum marketing & $\mathrm{X} 25$ \\
\hline Printing and Publishing & $\mathrm{X} 26$ \\
\hline Real estate & $\mathrm{X} 27$ \\
\hline Road transportation & $\mathrm{X} 28$ \\
\hline Textiles & $\mathrm{X} 29$ \\
\hline Foreign listings & \\
\hline
\end{tabular}

**Study codes are the author's formulation 
Appendix II. Sectors that Were Fully in Existence from 1984 to 2009 and Consequently Used as Study Sample

\begin{tabular}{|l|l|}
\hline SECTORAL CLASSIFICATION & STUDY CODE \\
\hline Agriculture/Agro-Allied & $\mathrm{X} 1$ \\
\hline Automobile and Tyre & $\mathrm{X} 3$ \\
\hline Banking & $\mathrm{X} 4$ \\
\hline Breweries & $\mathrm{X} 5$ \\
\hline Building Materials & $\mathrm{X} 6$ \\
\hline Chemicals and Paints & $\mathrm{X} 7$ \\
\hline Computer and Office equipment & $\mathrm{X} 8$ \\
\hline Conglomerates & $\mathrm{X} 9$ \\
\hline Construction & $\mathrm{X} 10$ \\
\hline Engineering Technology & $\mathrm{X} 11$ \\
\hline Food/Beverages and Tobacco & $\mathrm{X} 12$ \\
\hline Health Care & $\mathrm{X} 14$ \\
\hline Industrial/Domestic products & $\mathrm{X} 16$ \\
\hline Machinery marketing & $\mathrm{X} 19$ \\
\hline Packaging & $\mathrm{X} 24$ \\
\hline Petroleum marketing & $\mathrm{X} 25$ \\
\hline Printing and Publishing & $\mathrm{X} 26$ \\
\hline Textiles & $\mathrm{X} 29$ \\
\hline No of sectors $=18$ & \\
\hline
\end{tabular}

*** Study codes are the author's formulation

Appendix III. Data Collection/Research Instrument

\begin{tabular}{|c|c|c|c|c|c|c|c|c|c|c|}
\hline \multirow{2}{*}{$\mathbf{S} / \mathbf{N}$} & \multirow{2}{*}{$\begin{array}{l}\text { SECTORAL } \\
\text { CLASSFICATION }\end{array}$} & \multirow{2}{*}{$\begin{array}{l}\text { NAMES } \\
\text { COMPANIES } \\
\text { CLASSIFIED } \\
\text { INTO SECTOR }\end{array}$} & \multicolumn{8}{|c|}{ YEARS: (1984-2009) } \\
\hline & & & $\begin{array}{l}1984 \\
\text { NI (N'M) }\end{array}$ & $\begin{array}{l}1985 \\
\text { NI (N'M) }\end{array}$ & $\begin{array}{l}1986 \\
\text { NI (N'M) }\end{array}$ & $\begin{array}{l}1987 \\
\text { NI (N'M) }\end{array}$ & --- & - --- & - & $\begin{array}{l}2009 \\
\text { NI (N'M) }\end{array}$ \\
\hline \multirow[t]{2}{*}{1} & Banking Sector & $\begin{array}{l}\text { Coy } 1 \\
\text { Coy } 2 \\
\text { Coy N }\end{array}$ & $\begin{array}{l}X \\
X \\
X\end{array}$ & $\begin{array}{l}X \\
X \\
X\end{array}$ & $\begin{array}{l}X \\
X \\
X\end{array}$ & $\begin{array}{l}\mathrm{X} \\
\mathrm{X} \\
\mathrm{X}\end{array}$ & $\begin{array}{l}\mathrm{X} \\
\mathrm{X} \\
\mathrm{X}\end{array}$ & $\begin{array}{l}\mathrm{X} \\
\mathrm{X} \\
\mathrm{X}\end{array}$ & $\begin{array}{l}\mathrm{X} \\
\mathrm{X} \\
\mathrm{X}\end{array}$ & $\begin{array}{l}\mathrm{X} \\
\mathrm{X} \\
\mathrm{X}\end{array}$ \\
\hline & $\begin{array}{l}\text { Total for Banking } \\
\text { Sector }\end{array}$ & & X XX & X XX & $\mathrm{XXX}$ & X XX & X XX & X XX & X XX & X XX \\
\hline \multirow[t]{2}{*}{2} & Breweries & $\begin{array}{l}\text { Coy } 1 \\
\text { Coy } 2 \\
\text { Coy N }\end{array}$ & $\begin{array}{l}X \\
X \\
X\end{array}$ & $\begin{array}{l}X \\
X \\
X\end{array}$ & $\begin{array}{l}X \\
X \\
X\end{array}$ & $\begin{array}{l}X \\
X \\
X\end{array}$ & $\begin{array}{l}X \\
X \\
X\end{array}$ & $\begin{array}{l}\mathrm{X} \\
\mathrm{X} \\
\mathrm{X}\end{array}$ & $\begin{array}{l}\mathrm{X} \\
\mathrm{X} \\
\mathrm{X}\end{array}$ & $\begin{array}{l}X \\
X \\
X\end{array}$ \\
\hline & $\begin{array}{l}\text { Total for Brewery } \\
\text { sector }\end{array}$ & & X XX & $\mathrm{XXX}$ & $\mathrm{XXX}$ & $\mathrm{XXX}$ & X XX & X XX & $\mathrm{XXX}$ & XXX \\
\hline \multirow{3}{*}{$\begin{array}{l}\mid \\
\mid \\
\text { I } \\
\text { n }\end{array}$} & Y-Sector & $\begin{array}{l}\text { Coy } 1 \\
\text { Coy } 2 \\
\text { Coy N }\end{array}$ & $\begin{array}{l}X \\
X \\
X\end{array}$ & $\begin{array}{l}X \\
X \\
X\end{array}$ & $\begin{array}{l}X \\
X \\
X\end{array}$ & $\begin{array}{l}\mathrm{X} \\
\mathrm{X} \\
\mathrm{X}\end{array}$ & $\begin{array}{l}\mathrm{X} \\
\mathrm{X} \\
\mathrm{X}\end{array}$ & $\begin{array}{l}\mathrm{X} \\
\mathrm{X} \\
\mathrm{X}\end{array}$ & $\begin{array}{l}\mathrm{X} \\
\mathrm{X} \\
\mathrm{X}\end{array}$ & $\begin{array}{l}\mathrm{X} \\
\mathrm{X} \\
\mathrm{X}\end{array}$ \\
\hline & Total for sector $\mathrm{N}$ & & $\mathrm{XXX}$ & $\mathrm{XXX}$ & $\mathrm{XXX}$ & $\mathrm{XXX}$ & X XX & X XX & X XX & X XX \\
\hline & $\begin{array}{ll}\text { Gross } & \text { Domestic } \\
\text { Product } & \end{array}$ & & $\mathrm{XX}$ & $\mathrm{XX}$ & $\mathrm{XX}$ & $\mathrm{XX}$ & $\mathrm{XX}$ & $\mathrm{XX}$ & $\mathrm{XX}$ & $\mathrm{XX}$ \\
\hline
\end{tabular}

Notes: GDP $=$ Gross Domestic Product

$\mathrm{NI}=$ Net Sectoral Investment 
Appendix IV. Gross Domestic Product (GDP), Market Capitalization and Net Sectoral Investments of Quoted Companies In Nigeria, $1984-2009$ (N'M)

\begin{tabular}{|c|c|c|c|c|c|c|c|c|c|c|c|}
\hline YEAR & GDP & \multicolumn{2}{|c|}{ MKTCAP } & $\mathrm{X}_{3}$ & $\mathrm{X}_{4}$ & $\mathrm{X}_{5}$ & $\mathrm{X}_{6}$ & $\mathbf{X}_{7}$ & $\mathbf{X}_{8}$ & $X_{9}$ & $\mathbf{X}_{10}$ \\
\hline 1984 & 59622.5 & 5800 & 30.31 & 137.63 & 12343 & 504 & 150.6 & 192.5 & 29.8 & 911.64 & 119.6 \\
\hline 1985 & 67908.6 & 6400 & 30.23 & 156.19 & \begin{tabular}{|l|}
14667 \\
\end{tabular} & 540 & 154.6 & 180.8 & 39.3 & 1002 & 110.3 \\
\hline 1986 & 69147 & 7700 & 34.05 & 214.64 & 16256 & 574 & 306.2 & 193.5 & 42.4 & 1121 & 101.9 \\
\hline 1987 & 105223 & 8900 & 149.45 & 282.74 & 20177 & 615.6 & 319.8 & 208.4 & 46.9 & 1371 & 105 \\
\hline 1988 & 139085 & 9700 & 182.77 & 489 & 22729 & 509 & 389.5 & 214.4 & 90.14 & 2071 & 119 \\
\hline 1989 & 216797.5 & 12000 & 245.38 & 586.3 & 29454 & 1202.6 & 472.6 & 240.8 & 97.34 & 3195 & 142.5 \\
\hline 1990 & 267550 & 15900 & 297.68 & 633.1 & 33322 & 1666.5 & 1271.1 & 300 & 101 & 3990 & 151.5 \\
\hline 1991 & 312139.8 & 22600 & 293.7 & 616.2 & 42045 & 2055 & 1773.5 & 322.1 & 135.5 & 5043 & 526 \\
\hline 1992 & 532613.8 & 31270 & 549 & 489.2 & 70577 & 4091 & 2197.6 & 372.5 & 196 & 5962 & 652.7 \\
\hline 1993 & 683869.8 & 46900 & 716.8 & 735.5 & 95315 & 7077 & 3807 & 726 & 220.3 & 11189 & 683.7 \\
\hline 1994 & 899863 & 65500 & 878.7 & 1135.5 & 129005 & 17065 & 5147.8 & 909.8 & 389.1 & 16600 & 803 \\
\hline 1995 & 1933211.6 & 171100 & 1067.8 & 1529.2 & 244235 & 19516 & 8842 & 1126 & 551.5 & 19351 & 1210.3 \\
\hline 1996 & 2702719 & 285600 & 1114.6 & 1429.6 & 293085 & 19211.8 & 10396 & 1637.1 & 1023.3 & 24733 & 1596 \\
\hline 1997 & 2801973 & 292000 & 1361.4 & 1911.2 & 362080 & 22899 & 12249 & 1630.3 & 1077 & 26744 & 2434 \\
\hline 1998 & 2708431 & 263300 & 1494.3 & 2485.4 & 561522 & 24019 & 13189 & 1632.2 & 775 & 25678 & 2540 \\
\hline 1999 & 3194024 & 299900 & 1811 & 2473.2 & 628081 & 26226 & 21238 & 1906 & 638.7 & 25569 & 2405 \\
\hline 2000 & 4537640 & 478600 & 2180.6 & 2533.4 & 860179 & 36536 & 20891.5 & 1861.3 & 832.3 & 26821 & 2862 \\
\hline 2001 & 4685912 & 662600 & 3678.2 & 2316.9 & 1069202 & 39041 & 24714 & 2431.7 & 820.7 & 34093 & 3539 \\
\hline 2002 & 5403007 & 763900 & 5067.6 & 1803.5 & \begin{tabular}{|l|}
1271062 \\
\end{tabular} & 38596 & 27317 & 2351.3 & 826.8 & 37100 & 3418 \\
\hline 2003 & 6947820 & 1356000 & 4814.5 & 1877 & 1742537 & 44215 & 24377 & 2505.8 & 809.1 & 41186 & 3993 \\
\hline 2004 & 11411066 & 2112000 & 6120.4 & 2429.7 & 2263137 & 45406 & 29524 & 2772 & 1215.3 & 50663 & 4366 \\
\hline 2005 & 1455309 & 2900000 & 6480.7 & 6095 & 3380055 & 53255 & 24289 & 3197 & 913.1 & 51272 & 5227 \\
\hline 2006 & 18222790 & 5120000 & 8512.4 & 9432 & \begin{tabular}{|l|}
5437274 \\
\end{tabular} & 55800 & 42632 & 3252 & 62.8 & 60911 & 5007 \\
\hline 2007 & 22586710 & 13295000 & 11745 & 14615 & 8840792 & 67542 & 45577 & 4442 & 2421.5 & 82731 & 6447 \\
\hline 2008 & 25422990 & 9563000 & 32203 & 756 & 12145078 & 68706 & 71485 & 5147 & 1434 & 103306 & 7990 \\
\hline 2009 & 29111320 & 7032100 & 11271 & 1146 & 78792563 & 77961 & 85273 & 5908 & 1054 & 109141 & 10301 \\
\hline YEAR & $X_{11}$ & & $\mathbf{X}_{12}$ & $X_{14}$ & $\mathbf{X}_{16}$ & $X_{19}$ & $X_{24}$ & $\mathbf{X}_{25}$ & & $X_{26}$ & $X_{29}$ \\
\hline 1984 & 15.49 & & 605.8 & 132.31 & 103.6 & 18.09 & 58.4 & 293.5 & & 23.55 & 82.73 \\
\hline 1985 & 15.52 & & 673.2 & 140.37 & 102.1 & 24.91 & 53.3 & 320.1 & & 28.04 & 100.16 \\
\hline 1986 & 15.54 & & 871.7 & 212.12 & 104.5 & 21.38 & 93.7 & 328 & & 42.36 & 126.3 \\
\hline 1987 & 19.94 & & 1035.5 & 223.3 & 157.6 & 20.38 & 174.3 & 366.4 & & 25.56 & 148.9 \\
\hline 1988 & 24.5 & & 1225 & 273.3 & 181.3 & 39.05 & 236.3 & 407.1 & & 31 & 201.4 \\
\hline 1989 & 24.45 & & 1506 & 409.9 & 164.9 & 45.5 & 214.7 & 671 & & 32 & 549.4 \\
\hline 1990 & 52.7 & & 1704.2 & 734.1 & 245.7 & 46.12 & 253.6 & 868.5 & & 35.3 & 569.2 \\
\hline 1991 & 101.2 & & 2146 & 610.2 & 246.3 & 61.11 & 258.2 & 305.4 & & 40.3 & 35.3 \\
\hline 1992 & 40.5 & & 4015 & 1445.1 & 325 & 63.2 & 177.4 & 586.4 & & 28.2 & 1213.5 \\
\hline 1993 & 61.4 & & 6030.1 & 1895.4 & 844.3 & 63.5 & 732 & 1546 & & 54.6 & 2699 \\
\hline 1994 & 65.57 & & 9277.3 & 2024.9 & 1082 & 131.9 & 1356.3 & 2103 & & 33.7 & 3383 \\
\hline 1995 & 425.7 & & 12244 & 3368.6 & 1610.8 & 25.3 & 1933 & 4021.7 & & 99.7 & 4977 \\
\hline 1996 & 383.2 & & 15397 & 4487.1 & 2054 & 121.2 & 2667.3 & 5999.8 & & 284.6 & 5752 \\
\hline 1997 & 490.8 & & 16414 & 4722.5 & 1913.5 & 126.9 & 3621 & 7190.2 & & 325.5 & 6821 \\
\hline 1998 & 497 & & 16828 & 4531.4 & 2008 & 95.87 & 4820 & 9567.5 & & 792.3 & 7102 \\
\hline 1999 & 528.7 & & 20492 & 4184 & 2088 & 77 & 5882 & 11808 & & 2719.8 & 6756 \\
\hline 2000 & 539.5 & & 26312 & 5203 & 2324 & 84.1 & 6016 & 8406 & & 2510.3 & 5868 \\
\hline 2001 & 532.2 & & 29533 & 5443 & 2469.7 & 47.62 & 6675 & 9695 & & 2298.1 & 9877 \\
\hline 2002 & 1161.4 & & 42123 & 8113 & 2088 & 22.5 & 7128 & 19583 & & 1916.8 & 10688 \\
\hline 2003 & 796.4 & & 49663 & 8217 & 2963 & 237.2 & 7867 & 15663 & & 1765.6 & 10165 \\
\hline 2004 & 811.6 & & 52375 & 10467 & 3146 & 111.5 & 7702 & 29415 & & 838.7 & 9717 \\
\hline 2005 & 330 & & 65206 & 12473 & 3480 & 109 & 7791 & 40516 & & 973.3 & 9812 \\
\hline 2006 & 183.9 & & 62643 & 14630 & 3702 & 91 & 8857 & 48287 & & 1260.1 & 9016 \\
\hline 2007 & 292.2 & & 103625 & 15331 & 4354 & 9.4 & 10038 & 78197 & & 1647 & 7296 \\
\hline 2008 & 424 & & 154431 & 16076 & 6182 & 13.2 & 18282 & 76873 & & 7103 & 4727 \\
\hline 2009 & 400 & & 190708 & 15732 & 11858 & 14.12 & 18812 & 90553 & & 5389 & 5271 \\
\hline
\end{tabular}

Sources: (1) Central Bank of Nigeria (2005) and (2006), statistical Bulletins, Vols. 16 and 16

(2) Central Bank of Nigeria (2007, Annual Reports and Statement of Accounts.

(3) Nigeria Stock Exchange FACTS Book various years.

Notes: (a) $X_{1}-X_{n}$ represent the various sectors in the Nigerian Stock Exchange reflected in Appendix I.

(b) Gross Domestic product is at current basic prices. 